\title{
The Dynamics of Euphemisation in Legal Language: An Analysis of Legal Terms Referring to People with Disabilities Used in Poland and Spain
}

\author{
Joanna Nowak-Michalska ${ }^{1}$ (D)
}

Published online: 16 April 2020

(c) The Author(s) 2020

\begin{abstract}
Socio-political developments can result in a change of perception of people with disabilities and increase sensitivity towards language, especially legal language, used in relation to them. Some terms perceived as offensive or stigmatising are rejected in favour of more neutral and inclusive ones. Such terms can often be categorised as euphemisms or orthophemisms (Allan and Burridge in Forbidden Words, Taboo, and the Censoring of Language, Cambridge University Press, Cambridge, New York, 2006). With the passage of time, such new words frequently cease to serve their purpose and new ones need to be proposed to refer to a given concept (euphemism treadmill). In order to examine this issue, a number of legal terms denoting persons with disabilities used, currently and historically, in legal regulations in Poland and Spain are discussed. They are analysed in the context of changing the model of perception of people with disabilities (medical model vs. social model). Next, the differentiation between the so-called Identity-First Language (the term denoting disability comes first linearly) and Person-First Language (the term denoting disability comes second linearly, often in the form of a prepositional phrase), advocated by some members of the disability rights movement, is discussed. In this context, important syntactic and morphological differences (word-order, number of the term denoting disability) between English, serving as a model, and Spanish and Polish are focused on.
\end{abstract}

Keywords Legal language $\cdot$ Polish legal language $\cdot$ Spanish legal language Euphemism · Dysphemism · Orthophemism · Disability · Person-First Language · Identity-First Language

Joanna Nowak-Michalska

nowakj@amu.edu.pl; joannanowak@poczta.fm

1 Faculty of Modern Languages and Literatures, Adam Mickiewicz University, Poznań, Poland 


\section{Introduction}

Although the terminology used in legal acts should ideally be constant, it does change in accordance with the ever-changing reality which these acts concern. New terms are introduced as a result of scientific and technological advancement as well as developments in social and family life. In addition, socio-political changes can result in a change of perception of certain social groups, such as people with disabilities, and increase sensitivity towards the language used to talk about them. In consequence, some words perceived as offensive or stigmatising are rejected in favour of more neutral and inclusive ones. This also applies to terms used in legal language, which should be objective and neutral. The new terms are not always accepted in a given society immediately and are subject to discussion also in the social groups they refer to. This paper examines, from a synchronic and diachronic perspective (from the beginning of the twentieth century), selected legal terms referring to persons with disabilities ${ }^{1}$ used in national legal regulations in Poland and Spain. In their analysis, the change of the model of perception of people with disabilities is taken into account.

\section{Some Relevant Features of Legal Language}

As already mentioned, the language of legal regulations should be objective and neutral. It should not employ colloquialisms and dialectal or jargon expressions. Words in legal language should be used in their common meaning, while specialised terms should be employed only if this is needed to guarantee the necessary precision of a legal text (and they should be accompanied by legal definitions). It is recommended that the terminology is homogeneous and synonyms are avoided. These basic lexical requirements for legal language are formulated in scholarly and theoretical literature as well as in the Polish [27] and Spanish [23] principles of legislative technique. The Spanish principles also recommend that the language should be precise but plain and understandable for an average language user.

As a result, legal acts do not contain words which are considered colloquial, evaluative or offensive. This results from the requirements set forth in the principles of legislative technique and is also evidenced by research into legal texts. As indicated by Choduń's study [59: 162], these are made up of lexical units which are part of "vocabulary characterised as careful, devised and marked as formal (literary, official, professional, scientific)" [transl. mine]. Scholars, both Polish (Wróblewski [90: 120], Pieńkos [79: 98]) and Spanish (Iturralde Sesma [71: 44], Hernando Cuadrado [69: 51-55]), tend to divide the lexis of legal texts into the three following categories:

\footnotetext{
1 The analysis focuses on general terms referring to people with disabilities without taking into account terms denoting various kinds of disabilities. There are numerous definitions of disability, both in national legal systems and international law, but it does not seem necessary to deal with them in this paper.
} 
- General language terms used in general language meanings,

- General language terms used in modified or specified meanings,

- Specialised terms, typical of particular branches of law.

Since legal acts regulate multiple domains of human life and activity, they are penetrated by specialised terms concerning these domains [90: 118, 79: 98]. As observed by Prieto de Pedro [82: 171], this vocabulary can be of a varying degree of specialisation.

\section{Euphemisms in Legal Language}

One of the consequences of the requirement for legal language to be objective and emotionally unbiased is the use of euphemisms in legal acts. Numerous definitions of euphemisms have been proposed in scholarly literature, describing this phenomenon from various perspectives [cf. 58]. For the needs of the present study, we will look at the definition offered by Kany [72: V, apud 58: 727], who describes a euphemism as

the means by which a disagreeable, offensive or fear-instilling matter is designated with an indirect or softer term. Euphemisms satisfy a linguistic need. For his own sake as well as that of his hearers, a speaker constantly resorts to euphemisms in order to disguise an unpleasant truth, veil an offense, or palliate indecency.

As observed by Burridge [51: 455], a euphemism replaces a "dispreferred expression"- "one that is not desired or appropriate on a given occasion. Typically it denotes a taboo topic and so might alternatively be called a "taboo term"" [cf. also 47: 43ff and 58: 738]. Traditional taboo topics include the human body and its effluvia, sex, diseases, death etc. However, as indicated by Burridge [52: 452],

[t]he kinds of topics placed under taboo change over time. Since the 1980s, English speakers have shown a growing apprehensiveness of how to talk to and about others, particularly those perceived to be disadvantaged or oppressed.

She also observes that

[t]he push for equality and equal opportunity has given rise to legally enforceable fairness, sensitivity, and tolerance, and sanctions against what might be dubbed -ist language (such as sexist, racist, ageist, religionist language) have come to replace relaxing laws against profanity, blasphemy, and (sexual) obscenity [51: 458].

Euphemisms in legal language usually refer to sex, diseases, death, alcohol and drug addiction or some crimes, such as murder. However, they are not very frequent. In her article devoted to euphemisms in the texts of Polish legal acts [76: 123], Leśnik remarks that the greatest number of them can be found in the Penal Code [42] and the Code of Petty Offences [38]. In the legal acts which she analysed, including the 
Act on Promoting Sobriety and the Prevention of Alcoholism [44], the most numerous group of euphemisms concerns drinking alcohol, getting drunk and drunkenness in general [76: 126]. An analysis of the Polish Civil Code [36] and the Code of Civil Procedure [37] by Nowak-Michalska has shown that euphemisms in these legal acts are used rather occasionally [78: 107].

The opposite of a euphemism is dysphemism, which according to Allan and Burridge's definition [47: 42] is

a word or phrase with connotations that are offensive either about the denotatum and/or to people addressed or overhearing the utterance. (...) Dysphemistic expressions include curses, name-calling, and any sort of derogatory comment directed towards others in order to insult or to wound them.

Obviously, dysphemistic expressions should not—and, normally, do not-appear in the language of legal acts.

Casas Gómez [58: 738] proposes a new, broad definition of euphemism and dysphemism, paying special attention to their relativity. According to his approach, a euphemism or dysphemism is

a cognitive process of conceptualisation of a forbidden reality, which, manifested in discourse through the use of linguistic mechanisms including lexical substitution, phonetic alteration, morphological modification, composition or inversion, syntagmatic grouping or combination, verbal or paralinguistic modulation or textual description, enables the speaker, in a certain "context" or in a specific pragmatic situation, to attenuate, or, on the contrary, to reinforce a certain forbidden concept or reality.

This is represented graphically in the following diagram (Fig. 1).

Since euphemisms and dysphemisms are two opposite possibilities of expressing some content-polite and evasive versus offensive and vulgar-it is also possible to distinguish a third, intermediate possibility: direct and neutral expressions. Burridge, who terms such expressions orthophemisms (from Greek orthos 'proper, straight, normal' and phêmê 'speaking'), defines them as "direct terms that are neither sweet-sounding, evasive, overly polite (euphemistic), nor harsh, blunt or offensive (dysphemistic)" [51: 457]. Table 1 shows some examples of words belonging to each of these three categories.

However, as Burridge [51: 457] further remarks,

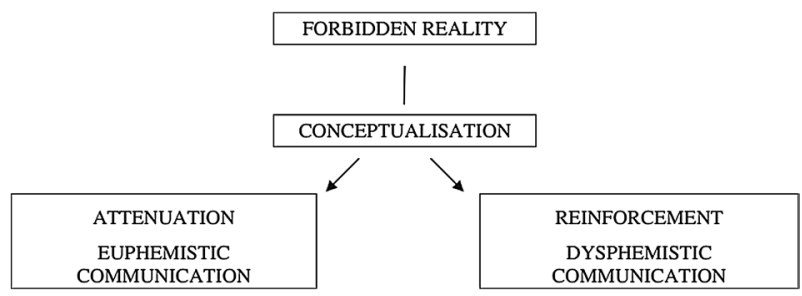

Fig. 1 Euphemisms and dysphemisms according to Casas Gómez [58: 738] 
Table 1 Euphemisms, orthophemisms, and dysphemisms [47: 32, 51: 457]

\begin{tabular}{lll}
\hline Euphemism & Orthophemism & Dysphemism \\
\hline To pass away & To die & To croak \\
Loo & Toilet & Shithouse \\
\hline
\end{tabular}

these descriptions are problematic because what determines them is a set of social attitudes or conventions that may vary considerably between dialect groups and even between individual members of the same community. Given there is such complexity and variety of opinions and attitudes, we are unlikely to ever find uniformity of judgment between speakers of even very similar social backgrounds. There can be no such thing as 'Everyman's euphemism' or 'Everyman's dysphemism'. X-phemisms (the union set of euphemisms, orthophemisms, and dysphemisms) are primarily determined from evaluating an expression within the particular context in which is it uttered.

Similarly, Casas Gómez [58: 731] claims that euphemisms are essentially a social phenomenon. He argues that "euphemistic/dysphemistic words no longer exist, only euphemistic/dysphemistic uses".

It seems that it is easier to identify expressions which are dysphemistic than to distinguish with certainty euphemisms from orthophemisms in any context. Taking this difficulty into consideration, in this paper the term euphemism, rather than orthophemism is used, as a blanket term, in order to avoid getting into too much detail in every analysed case.

\section{The Dynamics of Euphemisation}

As far as euphemisms are concerned, both in general and legal language, a certain type of dynamics can be observed: with the passage of time and changes affecting the socio-political reality, euphemisms cease to serve their purpose and new neutral and/or polite words have to be proposed to refer to a given concept. As Burridge [51: 460, cf. also 61: 53] argues,

[e]uphemisms frequently degenerate into dysphemisms through contamination by the taboo topic. If society's prejudiced perceptions continue to bubble away, eventually the euphemistic value will be undermined, and the negative connotations will reattach themselves, and a new euphemism must be found. For example, such is the stigma surrounding mental illness that any euphemism for the condition will quickly degenerate into dysphemism. This gives rise to a type of lexical treadmill effect.

This "euphemism treadmill" [47: 99, 80] or "euphemism carousel" [73: 13-15] can also be observed in terms referring to persons with disabilities used in legal regulations - as well as in general language usage - in Poland and Spain. Most probably, the terms in use at present are not the final stage in the series of expressions which 
can be employed in this function as the debate concerning the choice of the most accurate and suitable expressions is on-going.

\section{Terms Referring to Persons with Disabilities in Polish Legal Acts: A Historical Overview ${ }^{2}$}

In the first half of the twentieth century, three words, and their derivatives, were predominantly used to denote people with disabilities: kaleka, ułomny (osoba ułomna) and upośledzony. The first of them, kaleka, roughly translatable into English as 'cripple', entered the vocabulary of Polish (via Eastern Slavic from Turkish kalık 'defective') in the sixteenth century [50: 220]. It was used to refer to persons with disabilities over the course of four centuries. In contemporary Polish, this word and its abstract noun kalectwo, roughly: 'crippledom', definitely have negative and offensive connotations and can be regarded as dysphemisms. According to a leading dictionary of Polish, the word kaleka has two basic meanings, one of them being 'a person with a disability', and the other one, 'a clumsy person; clumsy oaf' [63, translation mine], classified as colloquial and dismissive. The terms kaleka and kalectwo were used on a regular basis in Polish legal language in the first half of the twentieth century (e.g. zakład dla kształcenia chorych, kalek, ciemnych, głuchoniemych $i$ niedorozwiniętych 'an educational institution for the ill, cripples, blind, deaf mute and retarded' [6: Art. 32]) to be gradually abandoned-however, not completely. Their remnants are still present in some legal regulations. For example, the term osoby kalekie 'crippled persons' is used in a law of 1991 [40: Art. 13.2.2] (as a category comprising "blind, deaf mute and infirm" persons), and the term kalectwo occurs in the Penal Code of 1997 [42: Art. 156]. Some contemporary legal scholars, e.g. Kurowski [74: 19], have explicitly argued that these terms should be removed completely from the legal system.

The other term occurring frequently in Polish legal regulations to refer to people with disabilities in this period is osoba ułomna 'a deficient person' (e.g. osoby umystowo lub fizycznie ułomne 'mentally or physically deficient persons', 1925 [34: Art. 10.4], osoby chore i fizycznie utomne 'ill and physically deficient persons', 1930 [26: Art. 5a]). ${ }^{3}$ The older sense of the adjective utomny 'deficient', dating back to the sixteenth century, was "such that can be broken (off), fragile" [50: 666]. In contemporary Polish, it has two interrelated meanings: (i) 'having physical defects, a cripple', and (ii) 'one who makes mistakes, has weaknesses, is imperfect or weak' [63, transl. mine]. Although the negative tinge of the second sense is evident, the phrase osoba ułomna was used in some later important legal acts, for instance, in the

\footnotetext{
2 The overview of the relevant terms, which, it should be stressed, are not always fully synonymous with each other, is based on my research conducted with the use of the LEX online legal information system (www.lex.pl). I used this database of Polish legal acts to perform targeted queries for selected terms in national legal acts issued since the beginning of the twentieth century.

${ }^{3}$ Here and in some other instances, the Polish terms are given in the nominative irrespective of the case in which they are used in the legal act cited.
} 
Polish Code of Civil Procedure of 1964 [37: Art. 600] and Family and Guardianship Code of 1964 [35: Art. 183].

The third term, upośledzony, and its abstract noun upośledzenie, occurs, for instance, in the phrases opieka nad (...) upośledzonymi umystowo "care for the mentally handicapped' (1923 [33: Art. 2c]) and wskutek upośledzenia fizycznego lub psychicznego 'as a result of a physical or mental handicap' (1921 [32: Art. 17]). Although functionally these words can be rendered into English as 'handicapped' and 'handicap', respectively, they carry a somewhat pejorative etymological burden, which leads to their negative connotations: upośledzony is the passive past participle of the verb upośledzać, which meant 'to treat somebody unfairly, to debase', and earlier: 'to leave behind, to disparage', and is derived from the adjective pośledni 'mean, second-rate, mediocre' [50: 668]. For these reasons, nowadays, they are mostly avoided. Nevertheless, some occurrences have survived in some legal acts, e.g. z powodu (...) upośledzenia umystowego 'because of a mental handicap' in the Petty Offences Code of 1971 [38: Art. 17.1] and, more recently, in 1989: osoby upośledzone fizycznie lub umysłowo 'physically or mentally handicapped persons' [39: Art. 39.1].

Partly as a euphemistic substitute for the terms discussed above, since they had begun to be perceived as dysphemisms, the terms inwalida and its abstract noun inwalidztwo were introduced into the language of law (although their denotation ranges are not identical). The internationalism inwalida (deriving from the same source as the English invalid, originally Latin invalidus 'weak, infirm'), appeared in Polish in the nineteenth century as a loanword from French, in the form inwalid (currently out of use) [48: 557]. Initially it denoted a soldier unfit for further active service due to physical inability. In the first half of the twentieth century, with its form changed to inwalida, the word acquired a legal meaning, especially after 1945, when it came to denote a person completely or partially unable to work. ${ }^{4}$ As observed by Dąbrowska, it was the foreignness of this term which had the alleviating effect [61: 144], at least in general language. ${ }^{5}$ In both acceptances, the focus is on a person's inability to fulfil their obligations, whether military (service) or social (work). Thus, it contributed - as did the term kaleka - to focussing the perception of disabilities on a person's defects (the rejection of this term on the grounds of its pejorative connotations has been advocated, among others, by Gąciarz [66: 25], Barbara Imiołczyk, representing the Office of the Polish Ombudsman [75] and Kurowski [74: 19]). ${ }^{6}$ It is one of the reasons why its use in legal language has been gradually restricted.

The term that replaced those discussed above, at least in some uses, in legal acts during the period 1960-1980 was osoby z niepetna sprawnościq or osoby o niepetnej

\footnotetext{
4 The adjective inwalidzki 'of or relating to the disabled' was employed in a compound term grupa inwalidzka 'invalidity group', which was used with an ordinal number from one to three to denote a particular degree of disability (currently: stopnie niepetnosprawności 'disability degrees' [43: Art. 3].

5 Its ousted predecessor, kaleka, was a word of foreign origin, too, but eventually ceased to be perceived as such. It appears that foreignness as a euphemising factor is also subject to detrition.

6 Another explanation is given by Bańkowski, who, in his etymological dictionary, claims that the word acquired negative connotations because, in the Polish People's Republic, invalidity rights used to be too easily granted, for political services and in order to eliminate unemployment [48: 557].
} 
sprawności, literally 'persons with incomplete ability' (the two prepositions, $o$ and $z$, are synonymous here). It seems that, initially, it was not a technical, clearly defined term referring directly to disability, as shown in the following phrases: pracownicy o niepetnej sprawności zawodowej 'employees with incomplete professional competence' (1973 [30: Annex 1, 4f]) and osoby o niepetnej sprawności do pracy 'persons with an incomplete ability to work' (1981 [29: Art. 5.3.2]). Some uses, however, seem to suggest a development towards a semantic specialisation, e.g. osoby $o$ niepetnej sprawności fizycznej (np. o stabym wzroku, przytępionym stuchu) 'persons with an incomplete physical ability (e.g. weak sight, impaired hearing)' (1960 [25: Art. 44.2]) and uczniowie z niepetna sprawnościa fizyczna lub umystowa 'pupils with an incomplete physical or mental ability' (1974 [28: Art. 6.1.4]). Arguably, the use of the negated adjective niepetny 'incomplete' had some euphemising effect. ${ }^{7}$

These latter uses seem to be the predecessors of a later, specialised term, osoba niepetnosprawna 'a disabled person', which appeared for the first time in Polish law in a 1982 law concerning specifically invalids and disabled persons [31: title and passim]. The word niepetnosprawny is an adjective composed of the negation nie- and the adjective petnosprawny 'fully able'. Structurally, it can be interpreted as a univerbation of any of the older phrases o niepetnej sprawności or $z$ niepetna sprawnościa meaning 'with incomplete ability'. Up until the present moment, constructions with this adjective seem to be the most common means of referring to people with disabilities employed in Polish national legal acts. Usually, the adjective is used with the noun osoby 'persons', but it can also modify other nouns which name particular groups of people (e.g. wyborcy niepetnosprawni 'disabled voters'). ${ }^{8}$ The corresponding abstract noun referring to the state of being a person with a disability used in Polish legal acts is niepetnosprawność 'disability'.

Slowly, but gradually, the new terms based on the adjective niepetnosprawny were substituted for inwalida and osoba utomna and their cognates fraught with pejorative connotations. In a law passed in 1996 [41], the term inwalidztwo and its cognates were not used any more [74: 19], having been replaced by niepetnosprawność and its cognates. ${ }^{9}$ Similarly, the term osoba utomna was replaced with the term osoba niepetnosprawna in the Polish Code of Civil Procedure [37: Art. 600] and Family and Guardianship Code [35: Art. 183] in 2007. This amendment was explicitly justified by the legislator with two reasons: the pejorative character of the adjective ułomny and the need for unifying legal terminology [92]. ${ }^{10}$

\footnotetext{
7 It should be noted, however, that the phrase niepetna sprawność was also used to refer to machines in the legal acts of that time, e.g. niepetna sprawność turbin wodnych 'incomplete efficiency of water turbines' [46: Art 8.1].

8 This adjective has also been substantivised, i.e. converted into a noun: niepetnosprawny (plural niepetnosprawni), but this form does not seem to be used in legal Polish.

9 Nonetheless, the term inwalidztwo appears in Poland's Constitution [7: Art. 67], which is posterior to the 1996 law mentioned above. The term inwalida also remains present in the Polish Civil Code [36: Art. 444].

10 Nevertheless, the corresponding abstract noun ułomność, derived from the adjective ułomny, can still be found in the Polish Civil Code [36: Art. 764].
} 
In some, rather more recent laws, the prepositional phrases $z$ niepetnosprawnościq 'with (a) disability' and $z$ niepetnosprawnościami 'with disabilities' modifying nouns, usually osoba 'person' or osoby 'persons', can be encountered. To all appearances, they have been modelled after the English prepositional expression persons with a disability. It seems, however, that as a rule, such constructions are only used if the disability in question is further specified, as in uczniowie $z$ niepetnosprawnościa intelektualnq $w$ stopniu umiarkowanym lub znacznym 'pupils with intellectual disability in a moderate or considerable degree' [45: Art. 18.2.2]. Their use without specification in national legal acts is rather exceptional (e.g. osoby $z$ niepetnosprawnościami 'persons with disabilities' in an act of 2005 [24: Annex 3, Treści nauczania, Art. 8]). Constructions with the adjective niepetnosprawny remain the preferred wording in this type of text (this is also the case in [45] mentioned above). It seems that the language of national laws is more resistent to the new prepositional construction than that of information and administration texts concerning people with disabilities and local legal regulations, in which it is more frequent (see Sect. 10 for a discussion of the two terms osoba niepetnosprawna and osoba $z$ niepetnosprawnościa in contemporary Polish).

\section{Terms Referring to Persons with disabilities in Spanish Legal Acts: A Historical Overview ${ }^{11}$}

At the onset of the twentieth century and for most of its duration the terms anormal, deficiente and subnormal were used in Spanish legal acts to refer to persons with disabilities (in most cases, however, the disability in question was of intellectual type).

The term anormal 'abnormal' was used, most significantly, in a royal decree of 1910 [18: title and passim] which created a national institution concerned with "the deaf mute, the blind and the abnormal" (Art. 2 specifies that the latter means mentally deficient). As observed by del Cura González, this term covered a category which was not clearly defined at that time: the defects and irregularities were primarily of the mental, emotional and moral, and in some cases also of the physical kind [62: 544]. Deficientes is the term used, perhaps in its earliest legal occurrence, in an act of 1934 [4] (apud [62: 558]) establishing the Patronato Nacional de Cultura de los Deficientes - a national patronage for the culture of the disabled. As del Cura González observes [62: 558], the name for this institution represented a "change of course" as far as the attitude towards people with disabilities is concerned, by explicitly including in this category persons with physical disabilities. The term deficientes remained in use for a long time; it appears, for instance, in a legal act

\footnotetext{
11 The overview is based on my research conducted with the use of the website of the Agencia Estatal Boletín Oficial del Estado (Spanish Official State Gazette Agency, www.boe.es), an online service archiving Spanish legal acts which enabled me to perform targeted queries for selected terms in national legal acts issued since the beginning of the twentieth century. As was the case with the Polish terms in Sect. 5, the Spanish terms presented here are not always fully synonymous with each other.
} 
of 1973, in whose title one reads: los deficientes físicos y mentales [17]. The term subnormal 'subnormal' is used as an adjective in a 1968 act in the phrase menores subnormales 'subnormal minors' [5: title and passim], to subsequently appear as a substantive, los subnormales, in a related act of 1970 [16: title and passim]. As observed by Mercè Carbó, a disabled rights activist and herself the mother of a child with an intellectual disability, the term subnormal had been introduced as one which would not offend and would be used instead of the then-current words such as oligofrenia, cretino, idiota or imbécil [57], i.e. as some sort of a euphemism.

All three terms discussed above point to some aberration from normality, which is evident in their prefixes: $a$-, denoting negation or absence, and $s u b$-, meaning 'below', or to lacking in some important quality, signalled by the prefix de- (deficiente being derived from Latin deficere 'to fail, to lack'). Their former relatively neutral or even euphemistic character is no longer apparent and nowadays they are considered offensive and should be classified as dysphemisms. This is also reflected in contemporary dictionaries, which class them as pejorativisms or insults. For instance, anormal and subnormal are characterised as being often used as an insult or pejoratively (u[sado] frec.[uentemente] c.[omo] insulto o en sent.[ido] despectivo) in the Dictionary of the Royal Spanish Academy [83], whereas the dictionary Clave describes deficiente as a word with a pejorative overtone and recommends that the term persona con discapacidad 'person with a disability' should be used instead (tiene un matiz despectivo, y por ello es preferible el uso de la expresión persona con discapacidad) [77: 551].

The term inválido is one of the two terms used to denote persons with disabilities in Spain in the second half of the twentieth century based on the stem válido "valid, able' (the other one, minusválido is discussed further on). The term inválido, with the negation prefix in-, means 'invalid, unable' (cf. Sect. 5 devoted to the Polish terms). This term often occurs in such phrases as inválidos militares 'military invalids' and inválidos de guerra 'war invalids', but here we are rather concerned with the so-called inválidos civiles 'civil invalids'. A term explicitly referring to a person's insufficient working potential was las personas inválidas para el trabajo 'persons invalid for work' (1940 [14: preamble]). Also the term minusválido, which subsequently became widely used to denote a disabled person in general (e.g. in the act of 1982 [9: title and passim]) and became the obligatory term in this sense in 1986 (see below), initially, e.g. in an act of 1968 [15], is used to refer to persons with reduced physical ability perceived as a factor impeding the gaining of normal work (as stated in Art. 1 of this document) (in this act, this term, as a rule, is an adjective, as in trabajadores minusválidos 'disabled workers' [e.g. 15: Art. 3a], only once a substantive: empleo de minusválidos 'employment of the disabled' [15: Art. 3b]).

The term used in the meaning of 'disabled, with a disability' in the Spanish Constitution of 1978 is disminuidos, occurring in the phrase los disminuidos fisicos, sensoriales y psíquicos [1: Art. 49]. Etymologically, it is related to the verb disminuir 'to diminish, to reduce'. Although some contemporary dictionaries characterise it as having "a pejorative tinge", ${ }^{12}$ it has been preserved in this document until the present

${ }^{12}$ According to the Clave Dictionary, this word has a pejorative tinge and therefore it is preferrable to use the expression persona con discapacidad [Tiene un matiz despectivo y por ello es preferible usar la expresión persona con discapacidad] ([77: 633], translation mine). In a disability style sheet for the mass 
day (in 2005, the then-Prime Minister José Luis Rodríguez Zapatero announced that he would propose to amend it to discapacitados [91], but this promise brought no tangible effects). It is far from being dominant in Spanish national legal acts but it occurs even in quite recent texts, e.g. in a European Council regulation of 2009, with the Spanish text having personas disminuidas [e.g. 22: Art. 68] (where the English and French wordings are handicapped persons and personnes handicapées, respectively). It is used either independently, as in the latter example, or with modifiers, e.g. las personas disminuidas en sus capacidades físicas, sensoriales o psíquicas, literally 'persons reduced in their physical, sensorial or mental abilities' (1985 [19: preamble]).

In 1986, a royal decree [20: Art. 1] explicitly stipulated that the terms subnormalidad and subnormal must be replaced by minusvalía and persona con minusvalía, respectively (with the necessary specifications). However, the terms introduced as euphemisms to replace dysphemisms acquired negative social connotations. For speakers of Spanish, valia refers to the worth of a person (cf. valer 'to be useful'), therefore, as argued by Fernández Iglesias [65: 36], the term minusvalia suggests belittling a person in all areas of their life, including the most important for the society, i.e. work.

This is arguably the reason why the officially sanctioned terms minusvalia, personas con minusvalía and minusválidos soon had to vie with a new, better-sounding word family: discapacidad 'disability' and personas discapacitadas 'disabled persons'. I was able to locate the latter in an act published as early as 1988 [21: Art. 2.8]. However, it is after 2000 that this phrase becomes really widespread.

This situation lasts until the use of terms referring to people with disabilities in legal acts was again regulated, in 2006, by the Law on the Promotion of Personal Autonomy and Care for People in the Situation of Dependency [11]. Its Additional Article 8 (Disposición adicional octava) stipulates that any normative text issued by the public administration from 2007 onwards must use the term persona $(s)$ con discapacidad 'person/s with a disability'. Significantly, this prepositional construction reflects the international trend in using prepositional terms modelled on the English construction, intended to neutralise the negative image of the group in question.

It should also be remarked that the term discapacidad is sometimes replaced by the noun limitaciones 'limitations'. This happens particularly when a specific type of disability is named, e.g. "Persona con discapacidad, es aquella que posee movilidad reducida o limitación sensorial" [A person with a disability is one who has reduced mobility or a sensory limitation] [10: Art. 3.1] or "las personas con discapacidad con limitaciones en su movilidad o en su percepción sensorial" [persons with a disability with limitations of their mobility or sensory perception] [13: Art. 62.2]. However, these two phrases seem also to be used as synonyms; for instance, the expressions "las personas sin discapacidad auditiva" [persons without auditory

Footnote 12 (continued)

media, published by the Real Patronato sobre Discapacidad (Royal Patronage for Disability), this term is included in a list of "erroneous, incorrect and obsolete words to avoid" [65: 31]. 
disability] [12: preamble, Part I] and "las personas con limitaciones auditivas" [persons with auditory limitations] [12: preamble, Part V] are both used in one legal act.

To conclude this section, an observation on how the discussed terminological evolution is reflected in the name of the institution mentioned at its beginning: it was created in 1910 as Patronato Nacional de Sordomudos, Ciegos y Anormales. In 1976 it was renamed Real Patronato de Educación Especial and in 1986-Real Patronato de Prevención y de Atención a Personas con Minusvalía, to eventually become Real Patronato sobre Discapacidad in 2000 [84].

\section{The Changing of the Model of Perception of People with Disabilities}

As was mentioned above, changes which affect terms referring to people with disabilities cannot be analysed only from the linguistic point of view. Socio-political changes, the activity of the disability rights movement and shifts in the models of perception of people with disabilities must be taken into consideration as well. As Burridge [51: 461] argues,

[s]ocietal shifts will always have linguistic repercussions, especially for the lexicon, and PC [political correctness]-driven changes are therefore partly a form of natural linguistic evolution in the face of more general social change.

The disability rights movement emerged in the 1960's in the United States and gradually started to achieve success, together with other social groups demanding civil rights at that time [85: 41]. It contributed to the change of the model of perception of people with disabilities from the medical model to the social one. The former model perceives disability as a medical problem of individuals and an aberration from the norm, viz. full health. Accordingly, disability is usually described by means of pejorative words such as 'dysfunction' or 'handicap'. People with disabilities are perceived as dependant 'objects' of charity, medical treatment and social protection [cf. 54: 98-100]. By contrast, the social model intends to replace this attitude with viewing persons with disabilities as 'subjects' and active members of a society, able to pursue their rights. In this model, responsibility for the difficulties experienced in everyday life by people with disabilities is shifted from the individual to society and the way it is organised. It is argued that societal barriers such as discriminatory or segregational education, prejudice, architectural barriers etc. exclude people with disabilities from taking part in social life with the same rights and possibilities as others [55: 137-139, 88: 14, 93]. Since the social model, too, has been criticised, as focusing too much on external barriers and underestimating personal experience [49: 83], yet another model has been proposed: the affirmation model. It is not, however, conceived of as being opposite to the social model but as one which develops and complements it [cf. 53, 56, 86]. ${ }^{13}$

\footnotetext{
13 In the context of changing attitudes towards people with disabilities and changing language used to refer to them, the framework of political correctness could also be resorted to. However, this complex topic (cf. [70] and [87]) goes beyond the scope of the present paper. Also, it should be observed that while political correctness is an important factor in the discussion in English-speaking countries, its
} 


\section{The Terms Used in the United Nations Convention on the Rights of Persons with Disabilities}

The turning point in the approach to disability which followed decades of efforts made by the United Nations to change attitudes towards persons with disabilities [cf. 88] was the proclamation of the (United Nations) Convention on the Rights of Persons with Disabilities (English version [3], Polish version [8], Spanish version [2]). The Convention and its Optional Protocol were adopted in 2006 and entered into force in 2008. The Convention refers directly to the values promoted by the social model, which can be seen, for example, in its Preamble and opening article:

Preamble (e) Recognizing that disability is an evolving concept and that disability results from the interaction between persons with impairments and attitudinal and environmental barriers that hinders their full and effective participation in society on an equal basis with others.

Art. 1: (...) Persons with disabilities include those who have long-term physical, mental, intellectual or sensory impairments which in interaction with various barriers may hinder their full and effective participation in society on an equal basis with others.

The official versions of the Convention are available in the six official UN languages: English, French, Spanish, Arabic, Russian and Chinese. Other language versions of the Convention available on the UN's official website are provided by external sources and, being not approved by the UN, can serve for informational purposes only. The terms used in the English and Spanish versions to denote persons with disabilities consist of a noun denoting a person or a group of people and the prepositional phrase instead of a noun with an adjective. Thus one reads: person with disabilities (two times person with disability) in English and persona con discapacidad in Spanish rather than disabled person and persona discapacitada, respectively.

The term used in the Polish translation of this document [8] is osoba niepetnosprawna 'disabled person'. The text has no comment explaining why this particular term has been chosen. One can only guess that this is due to its widespread use in Poland, both in legal acts and in general language. However, Kurowski [74: 21] observes that the ratification process in Poland witnessed repeated proposals to translate the title of the Convention with the use of the prepositional phrase construction: osoby z niepetnosprawnościami 'persons with disabilities'.

Footnote 13 (continued)

impact on the Polish and Spanish linguistic realities does not seem direct or obvious. For an overview of English (not necessarily legal) expressions referring to persons with disabilities, see [70: 194-199]. 


\section{Person-First Language Versus Identity-First Language}

In the present context, it is of importance that the two English expressions disabled person and person with disabilities differ from each other in the position of the modifier of the noun. If the modifier is an adjective (as in disabled person), it is the modifier (disabled) that precedes the noun. By contrast, if the modifier is a prepositional phrase (person with disabilities); it is the noun (person) that goes first. These two manners of expression are referred to by authors writing in English as Identity-First Language and People/Person-First Language, respectively. Person-First Language began to be used in the late twentieth century in the United States in order to stress that disability is not crucial in defining a person's identity but merely constitutes one of many features which characterise him or her. This naming convention is intended to prevent the stigmatisation of people and viewing them through the prism of their disabilities [cf. 68]. What is emphasised here is that a feature described by means of a prepositional phrase with the preposition with often denotes a feature detachable from the person in question (alienable property), e.g. a woman with a book. Even if what is being referred to in this way is a relatively stable physical property (cf. $a$ person with freckles), it is conceptualised, by virtue of an analogy, as one property out of many rather than an inalienable defining feature. ${ }^{14}$

However, as Halmari [68: 839] rightly observes,

the 'people first' proposal does not take language-typological issues into consideration. English happens to be a language that allows both pre- and postmodification. How would the 'people first' proposal address a language (e.g., Spanish), where postmodification is the norm?

Indeed, this pre- and postmodification differentiation is not possible in Spanish-nor in Polish. In each of these two languages, the expression denoting disability, regardless of whether it is an adjective or prepositional phrase, is always preceded by the noun denoting a person or group. Thus, irrespective of the construction one chooses, in Spanish and Polish it is always the people/person-first construction.

Halmari [68: 839] points out yet another important aspect of the person-first language:

The 'people first' proposal is also based on the idea that postmodification automatically takes the emphasis away from the disability. It ignores the principle of the functional sentence perspective, where what comes towards the end of the sentence is new information. The use of a euphemism in the form of a postmodified noun phrase automatically shines extra light on what it seeks to conceal.

\footnotetext{
${ }^{14}$ In French, the next step towards focusing on the external factors of disability has been effectuated with the introduction of the expression personne en situation de handicap 'person in the situation of disability' [cf. 60].
} 
In spite of the expanding use of Person-First Language all over the world, the debate as to which expression pattern is preferable is on-going, including among people with disabilities themselves. Person-First Language has also its critics:

For example, in a critique of a person-first language, some disability activists argue that separating the individual from the disability (i.e., deemphasizing it in spoken or written language) inadvertently promotes the view that disability is undesirable and that those touched by it are somehow less than human [64: 12].

It should also be observed at this point that in English, Spanish and Polish, which obviously differ from one another grammatically and morphologically, the prepositional construction is longer and hence less economical than the adjectival one.

\section{The Case of Polish: osoba niepełnosprawna 'Disabled Person' or osoba z niepełnosprawnością/niepełnosprawnościami 'Person with a Disability/Disabilities'?}

In Polish legal language, the use of the term osoba $z$ niepetnosprawnościa 'person with a disability' (or z niepetnosprawnościami 'with disabilities') has not become widespread yet. As mentioned above, the term generally used in national legal acts is osoba niepetnosprawna 'disabled person'. In the media and in general language usage, the corresponding noun niepetnosprawny (plural niepetnosprawni) is also frequently used. Constructions which imitate terms advocated and used in English appear in Polish more and more frequently; however, it seems that they are chosen chiefly by individuals or organisations dealing with the issue of disability on a daily basis or those generally more aware of the use of inclusive terminology. Being well aware of the changes which affect relevant terminology abroad, they share the convictions which underlie these developments. For instance, in the Office of the Polish Ombudsman, the prepositional phrase term, z niepełnosprawnościa, seems to be preferred. However, not every institution of this kind uses this term: in the Office of the Government Plenipotentiary for Disabled People (Biuro Pełnomocnika Rządu ds. Osób Niepełnosprawnych, note the English translation of its name, taken from the official website), the term osoba niepetnosprawna 'disabled person' is chosen.

The decision to opt for the prepositional phrase construction entails the question about the number, singular or plural, of the noun niepetnosprawność 'disability'. In English, which serves as a model for many other languages, the plural seems to be used more often. In Spanish, by contrast, the number is usually singular. As far as Polish is concerned, it seems that the singular-z niepetnosprawnościq-has been the predominant form thus far. As observed by Galasiński [67: 4-6], "The Polish niepetnosprawność 'disability' reluctantly turns into niepetnosprawności 'disabilities' and osoba z niepetnosprawnościami 'person with disabilities' sounds awkward in Polish" [transl. mine]. He proposes two possible solutions to this problem: Either to ignore that the number in English is plural and use the Polish noun niepetnosprawność in the singular, assuming that this form expresses a multitude of 
aspects of disability, or to use the plural niepetnosprawności, regardless of the awkwardness of such wording.

Summing up, there appears to be no simple answer to the question 'Which expression should be used when speaking or writing in Polish: osoba niepetnosprawna or osoba $z$ niepetnosprawnościq?' The supporters of the prepositional phrase construction [cf. 74: 21] claim that the term osoba niepetnosprawna confines a person to his or her disability and for this reason the prepositional phrase construction should be preferred.

As Galasiński [67: 4-6] puts it:

My sight defect does not determine who I am. Apart from the fact that I am "a person with a sight defect", I am an author, a professor, a father, and even an aikidoka and a runner. I am also a friend, a driver, an internet forum user and a fitness club member. All that "with a sight defect!" A person with a disability comes to resemble a person with a mole or perhaps with a briefcase or a doggy - in other words, with an attribute which does not determine his or her and which is detachable from him or her, at least in social sphere (transl. mine).

Podgórska-Jachnik [81: 30] considers this use "a manifestation of respecting the international tendency and adapting the Polish terminology to the English model widely used in international literature", translation mine). ${ }^{15}$ It can also be interpreted as a euphemising device since, as explained by Podgórska-Jachnik [81: 30], it "highlights a person's subjectivity and reduces their disability to one of their (many) attributes (...), in contrast to osoba niepetnosprawna, which "emphasises the limitation of ability and makes it the dominant feature characterising a person" (translation mine). She also remarks that some Polish lawyers concerned with the rights of people with disabilities stress that this distinction is not so conspicuous in Polish and there are no axiological grounds for a strict delimitation between these two terms. This author allows and recommends the use of these two terms interchangeably, especially since the use of many prepositional phrases may be grammatically awkward [81: 30].

If the prepositional phrase construction is to be used, what remains to be done is to choose the singular or plural number of the term niepetnosprawnośc. Whatever is the choice, it seems that relatively few people speak and write in this way in Poland. It goes without saying that whether a term becomes part of general language usage for longer is decided by its users. However, as Galasiński [67: 5] observes, everyday communication should be differentiated from the official one. People are unlikely to immediately begin to use the more complex expression z niepetnosprawnościa 'with a disability' in everyday communication, but this does not mean that one should not use it in formal documents, especially those which delineate social policy towards people with a disability. According to this author,

\footnotetext{
${ }^{15}$ It is interesting to note a sort of circular development concerning the grammatical forms of the recent Polish terms: The prepositional phrase z niepetna sprawnościa (or o niepetnej sprawności) was univerbised (synthesised into one word) into niepetnosprawny. From it, the abstract noun niepetnosprawność was derived, which again was used in a prepositional phrase: $z$ niepetnosprawnościa.
} 
public language, in particular the language of legal regulations (...), has, and should have, an educational function. It should modify the people's communicative habits and indicate the way of shaping the least stigmatising manner of referring to the group of people with disabilities [67: 5, translation mine].

Finally, Szahaj [87: 164] observes that as far as public discourse is concerned there is no, and there should not be, absolute freedom, especially if this would serve to humiliate others. Since it is crucial to know the opinion of the interested party itself, it seems justified to conduct a questionnaire survey on this issue among people with disabilities.

\section{Concluding Remarks}

Terms referring to people with disabilities in Polish and Spanish legal acts have been changing along with changing attitudes towards disability in the society and language used in reference to it, both in the national and international settings (UN Convention on the Rights of Persons with Disabilities). Some terms, for instance the Spanish subnormal 'subnormal' used around 20 years ago, would now be classed as dysphemisms. Some were introduced as euphemisms to replace a problematic term used earlier, for example the Spanish minusválido, but after some time they too ceased to serve their purpose and new terms needed to be coined and introduced. The current trends in terminology concerning people with disabilities are reflected in the UN Convention. In the English and Spanish official versions of this document, terms used to refer to people with disabilities consist of a noun denoting a person or a group of people and the prepositional phrase with disabilities (two times person with disability) in English and con discapacidad 'with disability' in Spanish. This Spanish term became obligatory in any normative text issued by public administration in Spain from 2007 onwards. In Poland, the use of the terms under discussion is not directly regulated, with the term commonly employed in Polish legal acts being the adjective niepetnosprawny 'disabled', used as a modifier of the noun osoba/osoby 'person/persons' or other nouns naming particular groups of people. The prepositional phrase $z$ niepetnosprawnościa 'with a disability' is used in some recent laws but rather infrequently, although some organisations and individuals promote its use in everyday communication instead of the adjective niepetnosprawny 'disabled'. It is being argued that pejorative terms such as inwalidztwo, inwalida, kalectwo should be eliminated from the Polish legal system [74: 20]. Obviously, it is not possible to force people to use less stigmatising terms in their ordinary conversations but a carefully devised official language and, in particular, language of legal regulations can serve as examples and play an important educational role.

It might seem that considering the number of problems which people with disabilities face in their everyday lives, the issues of language and, in particular, that of a label denoting them can seem trivial matters. It is, however, language that to a great extent shapes our awareness and the way we perceive other people and things. The choice of words used to refer to this group and the way of describing and representing them can therefore have a direct impact on how they feel and how they function 
in society. Nevertheless, one has to be aware that coining perfect terminology which would remain as such forever is impossible as the euphemism treadmill seems inevitable in the present case as well.

Open Access This article is licensed under a Creative Commons Attribution 4.0 International License, which permits use, sharing, adaptation, distribution and reproduction in any medium or format, as long as you give appropriate credit to the original author(s) and the source, provide a link to the Creative Commons licence, and indicate if changes were made. The images or other third party material in this article are included in the article's Creative Commons licence, unless indicated otherwise in a credit line to the material. If material is not included in the article's Creative Commons licence and your intended use is not permitted by statutory regulation or exceeds the permitted use, you will need to obtain permission directly from the copyright holder. To view a copy of this licence, visit http://creativecommons.org/licen ses/by/4.0/.

\section{References}

\section{Primary Sources (all sources Accessed 15 Mar 2020)}

1. Constitución Española aprobada por Las Cortes en sesiones plenarias del Congreso de los Diputados y del Senado celebradas el 31 de octubre de 1978. https://www.boe.es/legislacion/documentos/ ConstitucionCASTELLANO.pdf.

2. Convención sobre los Derechos de las Personas con Discapacidad. https://www.un.org/disabilities/ documents/convention/convoptprot-s.pdf.

3. Convention on the Rights of Persons with Disabilities. https://www.un.org/disabilities/documents/ convention/convoptprot-e.pdf.

4. Decreto de 3 de abril de 1934, M.I.P.B.A., Gaceta de Madrid. Diario Oficial de la República de 6/04/1934, n' 96 .

5. Decreto 2421/1968, de 20 de septiembre, por el que se establece en la Seguridad Social la asistencia a los menores subnormales. https:/www.boe.es/boe/dias/1968/10/07/pdfs/A14237-14239.pdf.

6. Dekret o obowiązku szkolnym (8 February 1919). http://prawo.sejm.gov.pl/isap.nsf/download.xsp/ WDU19190140147/O/D19190147.pdf.

7. Konstytucja Rzeczypospolitej Polskiej z dnia 2 kwietnia 1997 r. http://prawo.sejm.gov.pl/isap.nsf/ DocDetails.xsp?id=WDU19970780483.

8. Konwencja o prawach osób niepełnosprawnych. http://prawo.sejm.gov.pl/isap.nsf/download.xsp/ WDU20120001169/O/D20121169.pdf.

9. Ley $13 / 1982$, de 7 de abril, de integración social de los minusválidos. https://www.boe.es/eli/ es/1/1982/04/07/13/dof/spa/pdf.

10. Ley 1/1998, de 5 de mayo, de Accesibilidad y Supresión de Barreras Arquitectónicas, Urbanísticas y de la Comunicación. https://www.boe.es/boe/dias/1998/06/09/pdfs/A18972-18982.pdf.

11. Ley 39/2006, de 14 de diciembre, de Promoción de la Autonomía Personal y Atención a las personas en situación de dependencia. https://www.boe.es/buscar/act.php?id=BOE-A-2006-21990.

12. Ley $27 / 2007$, de 23 de octubre, por la que se reconocen las lenguas de signos españolas y se regulan los medios de apoyo a la comunicación oral de las personas sordas, con discapacidad auditiva y sordociegas. https://www.boe.es/buscar/pdf/2007/BOE-A-2007-18476-consolidado.pdf.

13. Ley 7/2014, de 13 de noviembre, de Garantía de los Derechos de las Personas con Discapacidad en Castilla-La Mancha. https://www.boe.es/buscar/doc.php?id=BOE-A-2015-1626.

14. Orden de 8 de noviembre de 1940 por la que se dictan normas sobre las Asociaciones de Inválidos que no gocen de una protección especial concedida. https://www.boe.es/datos/pdfs/BOE//1940/315/ A07745-07746.pdf.

15. Orden de 7 de noviembre de 1968 por la que se conceden ayudas a Centros de Empleo Protegida para Trabajadores Minusválidos. https:/www.boe.es/boe/dias/1968/11/30/pdfs/A17126-17126.pdf. 
16. Orden de 8 de mayo de 1970 por la que se aprueba el texto refundido de los Decretos 2421/1968, de 20 de septiembre, y 1076/1970, de 9 de abril, por los que se establece y regula la asistencia en la Seguridad Social a los subnormales. https://www.boe.es/boe/dias/1970/05/21/pdfs/A07871-07872 .pdf.

17. Orden de 1 de febrero de 1973 por la que se crea un Grupo de Trabajo y una Comisión de Dirección del mismo para el estudio de la situación actual de la atención a los deficientes físicos y mentales. https://www.boe.es/boe/dias/1973/02/03/pdfs/A02026-02026.pdf.

18. Real Decreto (24 January 1910) creating the Patronato Nacional de Sordomudos, Ciegos y Anormales. https://www.boe.es/datos/pdfs/BOE//1910/024/A00174-00176.pdf.

19. Real Decreto 334/1985, de 6 de marzo, de ordenación de la Educación Especial. https://www.boe. es/buscar/doc.php?id=BOE-A-1985-4305.

20. Real Decreto 348/1986 de 10 de febrero por el que se sustituyen los términos subnormalidad y subnormal contenidos en las disposiciones reglamentarias vigentes. https:/www.boe.es/boe/ dias/1986/02/21/pdfs/A06769-06769.pdf.

21. Real Decreto $736 / 1988$ de 8 de julio por el que se regula la tramitación de las reformas de importancia de vehículos de carretera y se modifica el artículo 252 del Código de la Circulación. https://boe. es/boe/dias/1988/07/16/pdfs/A22004-22007.pdf.

22. Reglamento (CE) $\mathrm{n}^{\circ} 1186 / 2009$ del Consejo, de 16 de noviembre de 2009, relativo al establecimiento de un régimen comunitario de franquicias aduaneras. https:/www.boe.es/buscar/doc. php?id=DOUE-L-2009-82400.

23. Resolución de 28 de julio de 2005 , de la Subsecretaría, por la que se da publicidad al Acuerdo del Consejo de Ministros, de 22 de julio de 2005, por el que se aprueban las Directrices de técnica normativa. https://www.boe.es/boe/dias/2005/07/29/pdfs/A26878-26890.pdf.

24. Rozporządzenie Ministra Edukacji Narodowej i Sportu z dnia 13 stycznia 2005 r. zmieniające rozporządzenie w sprawie podstawy programowej wychowania przedszkolnego oraz kształcenia ogólnego w poszczególnych typach szkół. http://prawo.sejm.gov.pl/isap.nsf/download.xsp/WDU20 050190165/O/D20050165.pdf.

25. Rozporządzenie Ministra Gospodarki Komunalnej z dnia 27 czerwca 1960 r. w sprawie bezpieczeństwa i higieny pracy w miejskich przedsiębiorstwach (zakładach) oczyszczania. http:// prawo.sejm.gov.pl/isap.nsf/download.xsp/WDU19600380228/O/D19600228.pdf.

26. Rozporządzenie Ministra Spraw Wojskowych z dnia 2 lipca 1930 r. wydane w porozumieniu z Ministrami: Spraw Wewnętrznych, Skarbu, Pracy i Opieki Społecznej, Sprawiedliwości, Rolnictwa, Przemysłu i Handlu, Robót Publicznych oraz Poczt i Telegrafów w sprawie wykonania ustawy z dnia 25 lipca 1919 r. o osobistych świadczeniach wojennych. http://prawo.sejm.gov.pl/isap.nsf/ download.xsp/WDU19300530444/O/D19300444.pdf.

27. Rozporządzenie Prezesa Rady Ministrów z dnia 20 czerwca 2002 r. w sprawie "Zasad techniki prawodawczej”. http://prawo.sejm.gov.pl/isap.nsf/download.xsp/WDU20021000908/O/D20020908. pdf.

28. Uchwała Nr 110 Rady Ministrów z dnia 3 maja 1974 r. w sprawie doskonalenia i rozwoju systemu orientacji i poradnictwa zawodowego. http://prawo.sejm.gov.pl/isap.nsf/download.xsp/WMP19 740190112/O/M19740112.pdf.

29. Uchwała Nr 170 Rady Ministrów z dnia 17 sierpnia 1981 r. w sprawie realizacji założeń narodowego planu społeczno-gospodarczego na 1981 r. w zakresie zatrudnienia. http://prawo.sejm.gov. pl/isap.nsf/download.xsp/WMP19810210196/O/M19810196.pdf.

30. Uchwała Nr 250 Rady Ministrów z dnia 9 listopada 1973 r. w sprawie służby pracowniczej w państwowych jednostkach organizacyjnych. http://prawo.sejm.gov.pl/isap.nsf/download.xsp/ WMP19730530297/O/M19730297.pdf.

31. Uchwała Sejmu Polskiej Rzeczypospolitej Ludowej z 16 września 1982 r. w sprawie inwalidów i osób niepełnosprawnych. http://prawo.sejm.gov.pl/isap.nsf/download.xsp/WMP19820220188/O/ M19820188.pdf.

32. Ustawa z dnia 18 marca 1921 r. o zaopatrzeniu inwalidów wojennych i ich rodzin oraz o zaopatrzeniu rodzin po poległych i zmarłych lub zaginionych bez własnej winy, których śmierć, względnie zaginięcie, pozostaje w związku przyczynowym ze służbą wojskową. http://prawo.sejm.gov.pl/isap. nsf/download.xsp/WDU19210320195/O/D19210195.pdf.

33. Ustawa z dnia 16 sierpnia 1923 roku o opiece społecznej. http://prawo.sejm.gov.pl/isap.nsf/downl oad.xsp/WDU19230920726/O/D19230726.pdf.

34. Ustawa z dnia 18 marca 1925 r. o izbach morskich. http://prawo.sejm.gov.pl/isap.nsf/download.xsp/ WDU19250360243/O/D19250243.pdf. 
35. Ustawa z dnia 25 lutego 1964 r. Kodeks rodzinny i opiekuńczy. http://prawo.sejm.gov.pl/isap.nsf/ DocDetails.xsp?id=wdu19640090059.

36. Ustawa z dnia 23 kwietnia 1964 r. Kodeks cywilny. http://prawo.sejm.gov.pl/isap.nsf/DocDetails .xsp?id=WDU19640160093.

37. Ustawa z dnia 17 listopada 1964 r. Kodeks postępowania cywilnego. http://prawo.sejm.gov.pl/isap. nsf/DocDetails.xsp?id=wdu19640430296.

38. Ustawa z dnia 20 maja 1971 r. Kodeks wykroczeń. http://prawo.sejm.gov.pl/isap.nsf/DocDetails .xsp?id=WDU19710120114.

39. Ustawa z dnia 17 maja 1989 r. o stosunku Państwa do Kościoła Katolickiego w Rzeczypospolitej Polskiej. http://prawo.sejm.gov.pl/isap.nsf/DocDetails.xsp?id=WDU19890290154.

40. Ustawa z dnia 12 stycznia 1991 r. o podatkach i opłatach lokalnych. http://prawo.sejm.gov.pl/isap. nsf/download.xsp/WDU19910090031/O/D19910031.pdf.

41. Ustawa z dnia 28 czerwca 1996 r. o zmianie niektórych ustaw o zaopatrzeniu emerytalnym i o ubezpieczeniu społecznym. http://prawo.sejm.gov.pl/isap.nsf/download.xsp/WDU19961000461/O/ D19960461.pdf.

42. Ustawa z dnia 6 czerwca 1997 r. Kodeks karny. http://prawo.sejm.gov.pl/isap.nsf/DocDetails .xsp?id=WDU19970880553.

43. Ustawa z dnia 27 sierpnia 1997 r. o rehabilitacji zawodowej i społecznej oraz zatrudnianiu osób niepełnosprawnych. http://prawo.sejm.gov.pl/isap.nsf/download.xsp/WDU19971230776/U/D1997 0776Lj.pdf.

44. Ustawa z dnia 26 października 1982 r. o wychowaniu w trzeźwości i przeciwdziałaniu alkoholizmowi. http://prawo.sejm.gov.pl/isap.nsf/download.xsp/WDU19820350230/U/D19820230Lj.pdf.

45. Ustawa z dnia 14 grudnia 2016 r. Prawo oświatowe. http://prawo.sejm.gov.pl/isap.nsf/download.xsp/ WDU20170000059/U/D20170059Lj.pdf.

46. Zarządzenie Ministra Górnictwa i Energetyki oraz Gospodarki Materiałowej i Paliwowej z dnia 14 stycznia 1987 r. w sprawie szczegółowych zasad eksploatacji turbin wodnych. http://prawo.sejm. gov.pl/isap.nsf/download.xsp/WMP19870040035/O/M19870035.pdf.

\section{Secondary Sources}

47. Allan, Keith, and Kate Burridge. 2006. Forbidden Words. Taboo and the Censoring of Language. Cambridge: Cambridge University Press.

48. Bańkowski, Andrzej. 2000. Etymologiczny stownik języka polskiego, vol. 1. Warszawa: Wydawnictwo Naukowe PWN.

49. Barnes, Colin, and Geof Mercer. 2008. Niepetnosprawność. Trans. T. Morawski. Warszawa: Wydawnictwo Sic! s.c.

50. Boryś, Wiesław. 2005. Słownik etymologiczny języka polskiego. Kraków: Wydawnictwo Literackie.

51. Burridge, Kate. 2006. Taboo, euphemism, and political corectness. In Encyclopedia of language and linguistics, ed. Keith Brown, 455-462. Boston: Elsevier Ltd.

52. Burridge, Kate. 2006. Taboo words. In Encyclopedia of language and linguistics, ed. Keith Brown, 452-455. Boston: Elsevier Ltd.

53. Cameron, Colin. 2014. The affirmation model. In disability studies: A student's guide, ed. Colin Cameron, 4-6. London: Sage Publications.

54. Cameron, Colin. 2014. The medical model. In Disability studies: A student's guide, ed. Colin Cameron, 98-100. London: Sage Publications.

55. Cameron, Colin. 2014. The social model. In Disability studies: A student's guide, ed. Colin Cameron, 137-139. London: Sage Publications.

56. Cameron, Colin. 2015. Turning experience into theory: The affirmation model as a tool for critical Praxis. Social Work \& Social Sciences Review 17 (3): 108-121. https://doi.org/10.1921/swssr.v17i3 .802 .

57. Carbó, Mercè, interviewed by Ramón Aymerich. 2000. Entrevista a Mercè Carbó, "la mamá del millón" y madre de una discapacitada mental: "Lourdes no sabía comer ni andar; hoy va en bicicleta, trabaja y cotiza". La Vanguardia, 26 marzo 2000, 40.

58. Casas Gómez, Miguel. 2009. Towards a new approach to the linguistic definition of euphemism. Language Science 31 (2009): 725-739. https://doi.org/10.1016/j.langsci.2009.05.001. 
59. Choduń, Agnieszka. 2007. Słownictwo tekstów aktów prawnych w zasobie leksykalnym współczesnej polszczyzny. Warszawa: Wydawnictwo TRIO.

60. de Coppet, Catherine. 2018. De l'infirmité à l'égalité des chances: la fabrique du mot «handicapé». https://www.franceculture.fr/histoire/de-linfirmite-a-legalite-des-chances-la-fabrique-du-mot-handi cape. Accessed September 10, 2019.

61. Dąbrowska, Anna. 1993. Eufemizmy współczesnego języka polskiego. Wrocław: Wydawnictwo Uniwersytetu Wrocławskiego.

62. del Cura González, Mercedes. 2012. Un patronato para los «anormales»: primeros pasos en la protección pública a los niños con discapacidad intelectual en España (1910-1936). Asclepio. Revista de Historia de la Medicina y de la Ciencia, vol. LXIV, $\mathrm{n}^{\circ}$ 2, julio-diciembre. 541-564. https://doi. org/10.3989/asclepio.2012.v64.i2.532.

63. Dubisz, Stanisław (ed.). 2013. Uniwersalny stownik jezyka polskiego, vol. 1-4. Warszawa: Wydawnictwo Naukowe PWN.

64. Dunn, Dana S. 2015. The social psychology of disability. New York: Oxford University Press.

65. Iglesias, Fernández, and José Luis. 2006. Guía de estilo sobre discapacidad para profesionales de los medios de comunicación. Madrid: Real Patronato sobre Discapacidad.

66. Gąciarz, Barbara. 2014. Model społeczny niepełnosprawności jako podstawa zmian w polityce społecznej. In Polscy niepetnosprawni: Od kompleksowej diagnozy do nowego modelu polityki spotecznej, ed. Barbara Gąciarz and Seweryn Rudnicki, 17-43. Kraków: Wydawnictwa AGH.

67. Galasiński, Dariusz. 2013. Osoby niepełnosprawne czy z niepełnosprawnością? Niepetnosprawność: zagadnienia, problemy, rozwiazania IV (9): 3-6.

68. Halmari, Helena. 2011. Political correctness, euphemism, and language change: The case of 'people first'. Journal of Pragmatics 43 (2011): 828-840. https://doi.org/10.1016/j.pragma.2010.09.016.

69. Cuadrado, Hernando, and Luis Alberto. 2003. El lenguaje jurídico. Madrid: Verbum.

70. Hughes, Geoffrey. 2010. Political correctness. A history of semantics and culture. Malden: Wiley-Blackwell.

71. Iturralde Sesma, Victoria. 1989. Lenguaje legal y sistema jurídico. Cuestiones relativas a la aplicación de la ley. Madrid: Tecnos.

72. Kany, Charles E. 1960. American-Spanish Euphemisms. Berkeley-Los Angeles: University of California Press.

73. Keyes, Ralph. 2010. Euphemania. Our love affair with euphemisms. Boston: Little Brown \& Company.

74. Kurowski, Krzysztof. 2014. Wolności $i$ prawa czlowieka $i$ obywatela z perspektywy osób z niepetnosprawnościami. Warszawa: Biuro Rzecznika Praw Obywatelskich.

75. Ławnicka, Bożena - PAP/Rynek Zdrowia. 2015. Eksperci: słowa "inwalida" i "kaleka" powinny zniknąć z języka publicznego. Rynek Zdrowia, https://www.rynekzdrowia.pl/Po-godzinach/Ekspe rci-slowa-quot-inwalida-quot-i-quot-kaleka-quot-powinny-zniknac-z-jezyka-publicznego, 14782 7,10.html. Accessed February 28, 2020.

76. Leśnik, Anna. 2011. Eufemizmy w tekstach polskich aktów prawnych. Ruch Prawniczy, Ekonomiczny i Socjologiczny 4: 119-129.

77. Maldonado Gonzáles, Concepción (ed.). 2000. Clave. Diccionario de uso del español actual. Madrid: Ediciones SM.

78. Nowak-Michalska, Joanna. 2017. Polish-Spanish legal translation. A parametric approach. Poznań: Wydawnictwo Naukowe CONTACT.

79. Pieńkos, Jerzy. 1999. Podstawy juryslingwistyki. Język w prawie - Prawo w języku. Warszawa: Oficyna Wydawnicza Muza S.A.

80. Pinker, Steven. 1994. The game of the Name. New York Times (April, 5.).

81. Podgórska-Jachnik, Dorota. 2014. Praca socjalna z osobami z niepetnosprawnościa i ich rodzinami. Warszawa: Centrum Rozwoju Zasobów Ludzkich.

82. Prieto de Pedro, Jesús. 1991. Lenguas, lenguaje y derecho. Madrid: Editorial Civitas.

83. Real Academia Española. Diccionario de la Lengua Española, https://dle.rae.es.

84. Real Patronato sobre Discapacidad: Historia. http://www.rpdiscapacidad.gob.es/conocenos/historia. htm. Accessed February 28, 2020.

85. Reid, Shannon. 2017. Policies of disability: From ugly ordinances to the disability rights movement. In Disability and U.S. politics: Participation, policy, and controversy, vol. I, ed. Dana Lee Baker, 37-60. Santa Barbara, CA: Praeger.

86. Swain, John, and Sally French. 2000. Towards an affirmation model of disability. Disability and Society 15 (4): 569-582. https://doi.org/10.1080/09687590050058189. 
87. Szahaj, A. 2004. E pluribus unum? Dylematy wielokulturowości i politycznej poprawności. Kraków: Universitas.

88. The United Nations and Disability: 70 years of the work towards a more inclusive world. https:// www.un.org/development/desa/disabilities/wp-content/uploads/sites/15/2018/01/History_Disability -in-the-UN_jan23.18-Clean.pdf. Accessed September 10, 2019.

89. UPIAS = Union of the Physically Impaired Against Segregation. 1976. Fundamental principles of disability. London: UPIAS.

90. Wróblewski, Bronisław. 1948. Język prawny i prawniczy. Kraków: Nakł. Polskiej Akademii Umiejętności.

91. Zapatero propone cambiar el término "disminuido" por "discapacitado" en la Carta Magna, El País, 3 December 2005, https://elpais.com/elpais/2005/12/03/actualidad/1133601418_850215.html. Accessed February 28, 2020.

92. Zieliński, Andrzej. 2017. Commentary on Art. 600 In Kodeks postępowania cywilnego. Komentarz. Wyd. 9., ed. Andrzej Zieliński. Warszawa: Wydawnictwo C.H. Beck. Retrieved from LEGALIS database https://legalis.pl/. Accessed September 10, 2019.

93. Zima-Parjaszewska, Monika. 2013. Artykuł 12 Konwencji ONZ o prawach osób z niepełnosprawnościami a ubezwłasnowolnienie w Polsce. Studia Prawnicze (PAN) 2 (194): 79-102.

Publisher's Note Springer Nature remains neutral with regard to jurisdictional claims in published maps and institutional affiliations. 